\title{
Bryophyllum pinnatum enhances the inhibitory effect of atosiban and nifedipine on human myometrial contractility: an in vitro study
}

\author{
S. Santos ${ }^{1,2}$, C. Haslinger ${ }^{1}$, M. Mennet ${ }^{3}$, U. von Mandach ${ }^{1}$, M. Hamburger ${ }^{2}$ and A. P. Simões-Wüst ${ }^{1 *}$ (D)
}

\begin{abstract}
Background: The herbal medicine Bryophyllum pinnatum has been used as a tocolytic agent in anthroposophic medicine and, recently, in conventional settings alone or as an add-on medication with tocolytic agents such as atosiban or nifedipine. We wanted to compare the inhibitory effect of atosiban and nifedipine on human myometrial contractility in vitro in the absence and in the presence of B. pinnatum press juice (BPJ).
\end{abstract}

Methods: Myometrium biopsies were collected during elective Caesarean sections. Myometrial strips were placed under tension into an organ bath and allowed to contract spontaneously. Test substances alone and at concentrations known to moderately affect contractility in this setup, or in combination, were added to the organ bath, and contractility was recorded throughout the experiments. Changes in the strength (measured as area under the curve (AUC) and amplitude) and frequency of contractions after the addition of all test substances were determined. Cell viability assays were performed with the human myometrium hTERT-C3 and PHM1-41 cell lines.

Results: BPJ $(2.5 \mu \mathrm{g} / \mathrm{mL})$, atosiban $(0.27 \mu \mathrm{g} / \mathrm{mL})$, and nifedipine $(3 \mathrm{ng} / \mathrm{mL})$, moderately reduced the strength of spontaneous myometrium contractions. When BPJ was added together with atosiban or nifedipine, inhibition of contraction strength was significantly higher than with the tocolytics alone $(p=0.03$ and $p<$ 0.001 , respectively). In the case of AUC, BPJ plus atosiban promoted a decrease to $48.8 \pm 6.3 \%$ of initial, whereas BPJ and atosiban alone lowered it to $70.9 \pm 4.7 \%$ and to $80.9 \pm 4.1 \%$ of initial, respectively. Also in the case of AUC, BPJ plus nifedipine promoted a decrease to $39.9 \pm 4.6 \%$ of initial, at the same time that BPJ and nifedipine alone lowered it to $78.9 \pm 3.8 \%$ and $71.0 \pm 3.4 \%$ of initial. Amplitude data supported those AUC data. The inhibitory effects of BPJ plus atosiban and of BPJ plus nifedipine on contractions strength were concentration-dependent. None of the test substances, alone or in combination, decreased myometrial cell viability.

Conclusions: BPJ enhances the inhibitory effect of atosiban and nifedipine on the strength of myometrial contractions, without affecting myometrium tissue or cell viability. The combination treatment of BPJ with atosiban or nifedipine has therapeutic potential.

Keywords: Bryophyllum pinnatum, Atosiban, Nifedipine, Preterm, Myometrium, Contractility

\footnotetext{
* Correspondence: anapaula.simoes-wuest@usz.ch

'Department of Obstetrics, University Hospital Zurich, Schmelzbergstrasse 12/

PF 125, 8091 Zurich, Switzerland

Full list of author information is available at the end of the article
}

(c) The Author(s). 2019 Open Access This article is distributed under the terms of the Creative Commons Attribution 4.0 International License (http://creativecommons.org/licenses/by/4.0/), which permits unrestricted use, distribution, and reproduction in any medium, provided you give appropriate credit to the original author(s) and the source, provide a link to the Creative Commons license, and indicate if changes were made. The Creative Commons Public Domain Dedication waiver (http://creativecommons.org/publicdomain/zero/1.0/) applies to the data made available in this article, unless otherwise stated. 


\section{Background}

Preterm birth, defined as birth before 37 weeks of pregnancy, affects 5 to $18 \%$ of pregnancies. It is the number one cause of neonatal deaths, and the second leading cause of childhood death under 5 years of age [1-3]. Delaying preterm delivery frequently involves pharmacological inhibition of myometrial contractions (tocolysis) [4]. The main aim of a tocolytic treatment is to delay delivery long enough (24-48 h) for corticosteroid administration to the mother to achieve foetal lung maturation, and for transfer of the mother to a perinatal centre $[4,5]$. Several types of tocolytics are currently in use $[4,6,7]$. Atosiban, a competitive oxytocin-vasopressin antagonist [8], and nifedipine, a calcium channel-blocking agent [9], are often given as first tocolytic treatment since they have good efficacy to side-effect ratios $[10,11]$. A recent randomised study showed that atosiban and nifedipine resulted in similar perinatal outcomes [12]. Long term (>1 week) tocolysis is seldom pursued and rarely achieved even though pregnancy prolongation favours perinatal outcomes [13].

Bryophyllum pinnatum (Lam.) Oken [syn. Kalanchoe pinnata (Lam.) Pers.; family Crassulaceae] is a perennial succulent plant that grows widely in tropical and subtropical areas. In Europe, $B$. pinnatum started to be used in anthroposophic medicine [14] as treatment of preterm labour $[15,16]$. Retrospective analyses of the clinical practice revealed good efficacy of $B$. pinnatum preparations in this indication [15, 16], which was corroborated by a matched pair study [17]. Results of a prospective randomised trial on acute tocolysis are in line with good efficacy, but have to be interpreted with caution since - due to poor recruitment rate - the study was discontinued before completion [18]. All clinical studies demonstrated a very good tolerability of $B$. pinnatum. The use of such preparations in the treatment of pre-term contractions was supported by in vitro studies $[19,20]$.

An assessment of the internal treatment recommendations in the main Swiss obstetrics centres showed that $B$. pinnatum preparations are being prescribed for the treatment of preterm contractions [21]. This is in line with a Swiss online survey which showed that in approximately $3 / 4$ of the cases $B$. pinnatum preparations are administered in combination with synthetic tocolytics [22]. Comparable results were obtained in a retrospective analysis of the clinical practice at the University Hospital Zurich [23]. It is still not clear how $B$. pinnatum preparations influence the effects of tocolytics on myometrial contractility. We here compare the inhibitory effect of atosiban and nifedipine on human myometrial contractility in vitro in the absence and in the presence of $B$. pinnatum press juice (BPJ). Given a potentially synergistic effect of these substances, the question is of clinical interest.

\section{Methods}

\section{Test substances}

B. pinnatum leaves were harvested on the 25 March 2014 from $B$. pinnatum plants cultivated at the Medical Plants Garden located in S. Roque, Brazil, and that descend from seedlings brought from Weleda AG, Arlesheim, Switzerland, in the past. Plant collection did not affect Brazilian biodiversity and was done in accordance to Brazilian Environmental and Biodiversity laws, mainly Provisional Measure 2186-16 from 23 August 2001 that rules access to genetic resources and traditional knowledge. The Medical Plants Garden from S. Roque belongs to Weleda Brazil and the harvested B. pinnatum plants were identified by the Weleda employees Moacyr Copani and Paulo Copani. A voucher specimen ZSS 29717 was deposited at the Zurich Succulent Plant Collection. Leaves were sent by airmail to Weleda Arlesheim, Switzerland, in a refrigerated box. BPJ was obtained by mechanical pressing in a roller, the procedure used in the first step of the production of the active ingredient of Weleda Bryophyllum 50\% chewable tablets (Weleda AG, Arlesheim). Unfiltered press juice was kept at $-80^{\circ} \mathrm{C}$ until use.

Atosiban (Tractocile ${ }^{\varpi} 7.5 \mathrm{mg} / \mathrm{mL}$ injectable solution), was purchased from Ferring Pharmaceuticals, Baar, Switzerland. Nifedipine was obtained from Sigma-Aldrich (purity $\geq 98 \%$, N7634-1G); a $3.7 \mu \mathrm{g} / \mathrm{mL}$ stock solution was prepared in DMSO.

\section{Design}

The ethics committee of canton Zurich approved the study with human myometrium biopsies (KEK-ZH-Nr. 2014-0717, approval date 12.05.2015). Patients were asked prior to elective caesarean sections to donate a myometrium biopsy if the following inclusion criteria were fulfilled: single pregnancy, planned first caesarean section, negative HIV test, age $>18$ years, and no tocolysis within 2 weeks before caesarean section.

A myometrial biopsy of approx. $5 \mathrm{~g}$ was taken from each study participant at the cranial margin of the uterotomy. The myometrial biopsy was immediately stored in Ringer solution and transported to the lab. Longitudinal strips of muscle of about $15 \times 2 \times 1 \mathrm{~mm}$ were cut and mounted in a myograph bath chamber. Each of the four myograph chambers contained $6 \mathrm{~mL}$ of Krebs solution (in mM: $\mathrm{NaCl} 118$, $\mathrm{NaHCO}_{3}$ 24.9, $\mathrm{KCl}$ 4.7, $\mathrm{KH}_{2} \mathrm{PO}_{4} 1.24, \mathrm{CaCl}_{2} 2.48, \mathrm{MgSO}_{4}$ 1.21, Glucose 10, EDTA 0.034; $\mathrm{pH}=7.4$ ), with temperature regulated at $37^{\circ} \mathrm{C}$ and bubbled with $95 \% \mathrm{O}_{2}$ and $5 \% \mathrm{CO}_{2}$ (PanGas, Dagmersellen, Switzerland). Contractions were recorded with a DMT800MS myograph (Danish Mayo Technology, Denmark) and transferred to a personal computer via a transducer (ADInstruments PowerLab 4/30). Myometrial strips were allowed to contract spontaneously (which took in most cases approximately $2 \mathrm{~h}$ ). During this time, the Krebs solution was replaced every $30 \mathrm{~min}$. 
In preliminary experiments, concentrations of atosiban, nifedipine and BPJ were determined that would lead to moderate lowering (by 20-30\%) of contraction strength. These concentrations were used in the main combination experiments, performed as described below. In preliminary experiments, two slightly different experimental protocols appeared equally promising. We used both protocols, one for the experiments with atosiban, and the second for nifedipine, to find out whether one of the protocols would result in lower standard error of the means (SEM) values.

\section{Effect of the combination of BPJ with atosiban or with nifedipine on myometrial contractility}

In all cases, regular spontaneous myometrial contractions in amplitude and frequency were recorded for $30 \mathrm{~min}$.

When the effects of the combination of BPJ with atosiban were being studied, each one of four strips was treated with one test substance, and contractility was recorded for additional $30 \mathrm{~min}$. Test substances were: Krebs solution, $5 \mu \mathrm{L}$ (control; $n=11$ ); BPJ, $15 \mu \mathrm{L}(0.25 \%$ final concentration, corresponding to $2.5 \mu \mathrm{g} / \mathrm{mL} ; n=13)$; atosiban, $4.3 \mu \mathrm{L}$ of $375 \mu \mathrm{g} / \mathrm{mL}(0.27 \mu \mathrm{g} / \mathrm{mL}$ final concentration; $n=11$ ); and BPJ and atosiban combined (same concentrations, $n=12$ ). Temporal and vehicle controls were run in parallel in each experiment to access the decay in contractility of the myometrium with time.

To study the combination of BPJ with nifedipine, Krebs solution, $5 \mu \mathrm{L}$ (control; $\mathrm{n}=13$ ) or nifedipine, $5 \mu \mathrm{L}$ of $3.7 \mu \mathrm{g} / \mathrm{mL}$ (final concentration $3 \mathrm{ng} / \mathrm{mL} ; \mathrm{n}=11$ ) was added to two chambers each, contractility was recorded for 30 min and thereafter $15 \mu \mathrm{L}$ of BPJ (final concentration of
$0.25 \mu \mathrm{g} / \mathrm{mL} ; n=10)$ was added to all four chambers. This resulted in two chambers with BPJ alone and two chambers with the combination of nifedipine with BPJ. After BPJ addition, contractions were recorded for $30 \mathrm{~min}$ (Fig. 1b).

\section{Dose-dependency effect of combination treatments on myometrial contractility}

To find out whether the effect of the combination treatments would further increase at higher concentrations, a previously described approach was followed [24]. In brief, when spontaneous contractions were regular for $20 \mathrm{~min}$, Krebs solution was added (addition 0), and contractility was recorded for $20 \mathrm{~min}$. Then, each strip was treated with one test substance by adding 4 times, at time intervals of $20 \mathrm{~min}$, the same volume of a stock solution. Test solutions included: control, $5 \mu \mathrm{L}$ Krebs solution; BPJ, $15 \mu \mathrm{L}$; combination of BPJ $(15 \mu \mathrm{L})$ plus atosiban $(4.3 \mu \mathrm{L}$ of $375 \mu \mathrm{g} / \mathrm{mL})$ or BPJ $(15 \mu \mathrm{L})$ plus nifedipine $(5 \mu \mathrm{L}$ of $3.7 \mu \mathrm{g} /$ $\mathrm{mL})$. For each substance tested, 5 different biopsies were used $(n=5)$.

\section{Vitality of myometrial strips}

The exposure to the different test substances was followed by a 30-min washing period where Krebs solution was changed several times (at 5, 10, 20 and $30 \mathrm{~min}$ ). Vitality of the strips was determined at the end of the experiment ( $30 \mathrm{~min}$ after washing) by observation of spontaneous contractions. In all cases, strips were contracting and data were included in the present analysis.

A

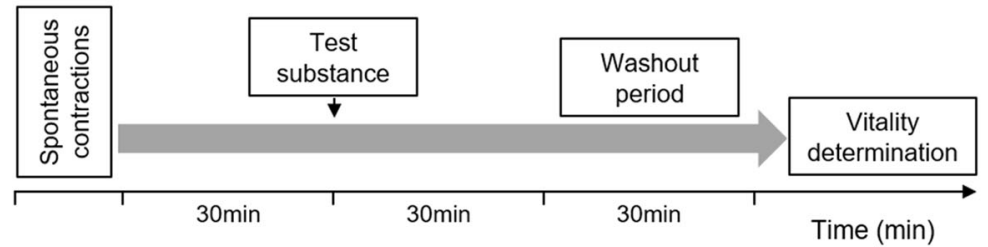

B

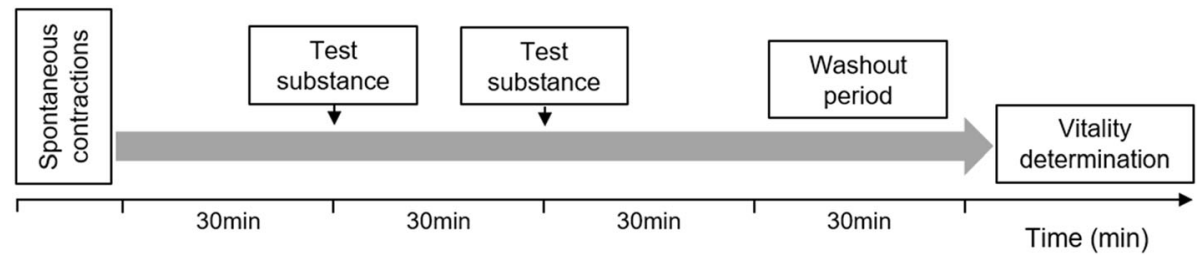

Fig. 1 Experimental design for measurement of myometrial contractions. Test substances were added to the organ bath when myometrium strips had been contracting regularly for $30 \mathrm{~min}$. When the effects of BPJ and/or atosiban were being studied (a), Krebs solution (control), BPJ, atosiban, or the combination of BPJ and atosiban were added, and contractility was recorded for $30 \mathrm{~min}$. When the effects of BPJ and/or nifedipine were being studied (b), Krebs solution (control; two strips) or nifedipine (two strips) was added, contractility was recorded for 30 min, and then BPJ was added to all chambers. Exposure to test substances was followed by a 30 min washout step, with change of Krebs solution at $5,10,20$ and $30 \mathrm{~min}$ 


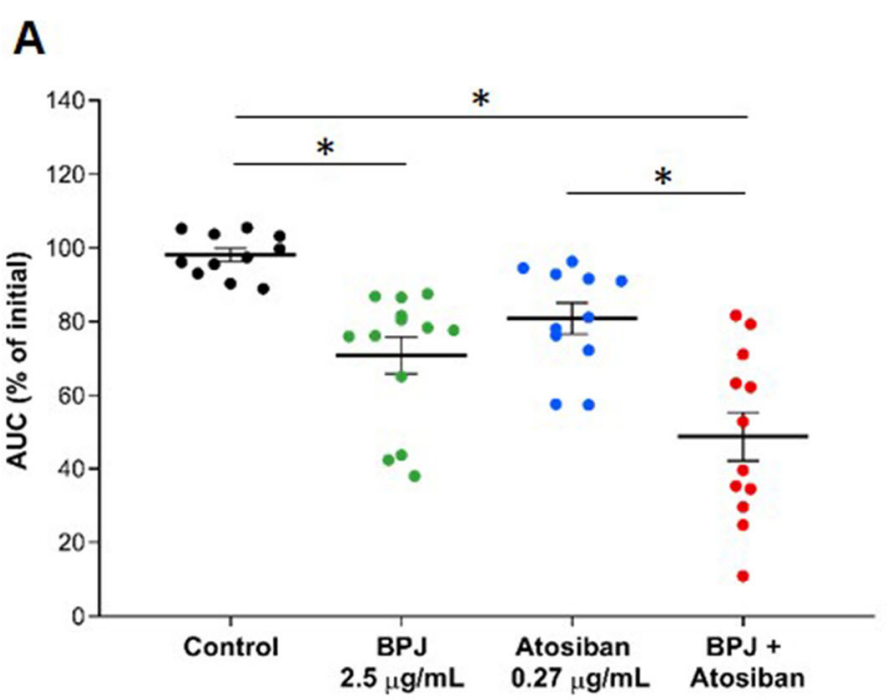

B
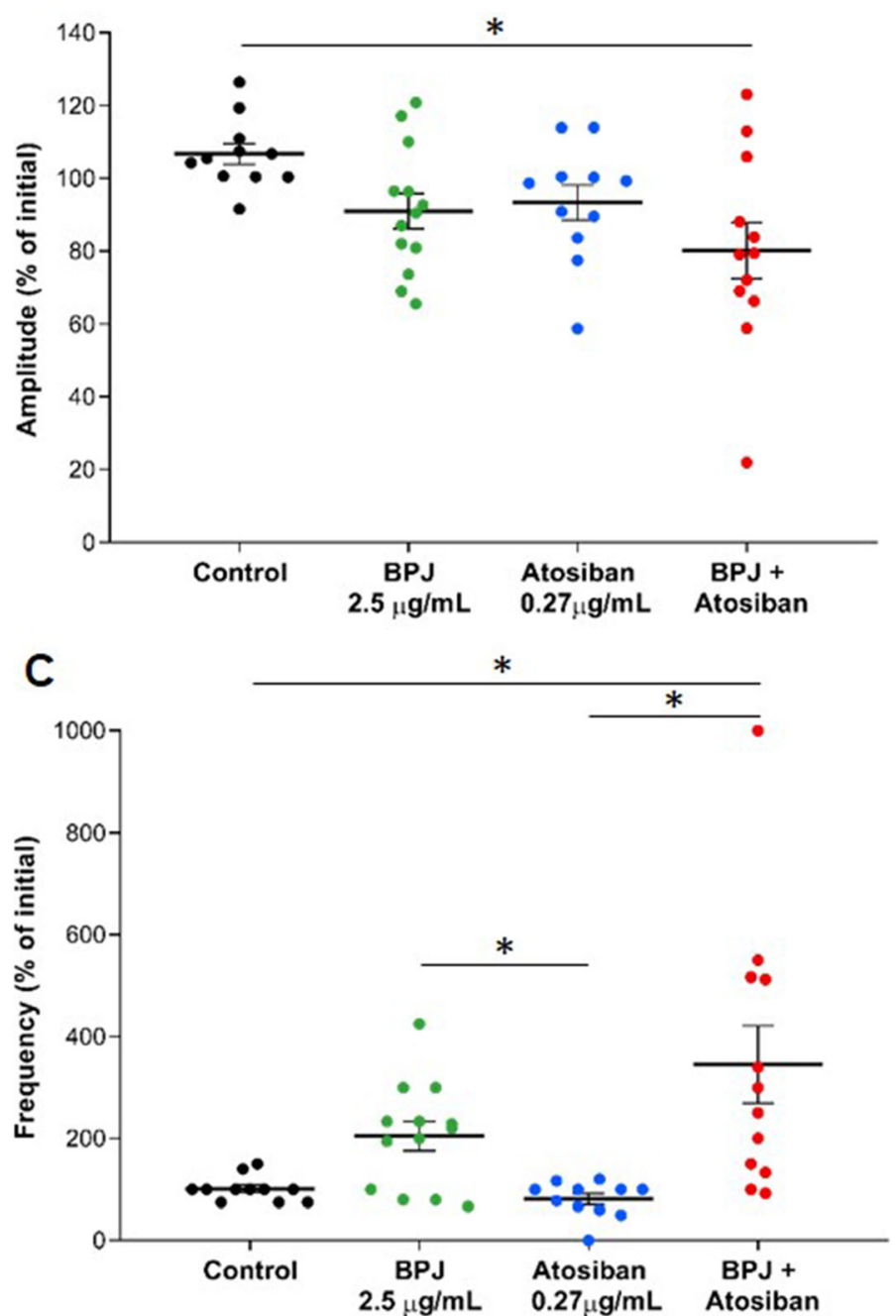

Fig. 2 (See legend on next page.) 
(See figure on previous page.)

Fig. 2 Effect of BPJ, atosiban, and the combination of BPJ with atosiban on human myometrial contractility in vitro. BPJ (green; $15 \mu \mathrm{L}$ ), atosiban (blue; $4.3 \mu \mathrm{L}$ of $375 \mu \mathrm{g} / \mathrm{mL}$ ) or their combination (red, same concentrations) were added to the myograph chamber. The scatter dot plot shows the AUC (a), the amplitude (b), and the frequency (c) of contractions expressed as percentage of initial. Krebs solution was used as negative control (black, $5 \mu \mathrm{L}$ ). Data were obtained from 11 to 15 different biopsies $(n=11-15)$ and are presented as mean value \pm SEM. ${ }^{*} p<0.05$

\section{Myograph data processing}

Myometrium contractions were recorded by LabChart Pro 8.0.6 (ADInstruments, Germany) and analysed with the peak analysis module. For each contraction, the area under the curve (AUC) and the amplitude were analysed. Depending on the type of experiments, for each 20 or $30 \mathrm{~min}$ interval, the average AUC and average amplitude were calculated, and the number of contractions was noted (frequency). Initial values of AUC, amplitude and frequency of spontaneous contractions (before any addition) were set at $100 \%$. Effects after addition of test substances were expressed as percentage of initial. When studying the combination of BPJ and atosiban and in all dose-dependency experiments, the values obtained in one strip per biopsy were used for further statistical analyses. When investigating the combination of BPJ and nifedipine, two strips per biopsy were used to determine the effect of each substance (BPJ, nifedipine, BPJ plus nifedipine, and control). In this case, average values of the two determinations were calculated and used for further statistical analyses.

\section{Viability assays in myometrium cell lines}

Human myometrial telomerase reverse transcriptase cell line (hTERT-C3) [25, 26], provided by M. Grãos (University of Coimbra, Portugal), was cultured in an 1:1 mixture of DMEM and F-12 supplemented with antibiotics $(100 \mathrm{U} / \mathrm{mL}$ penicillin and $100 \mu \mathrm{g} / \mathrm{mL}$ streptomycin) and $10 \%(\mathrm{v} / \mathrm{v})$ heat-inactivated foetal bovine serum (FBS) (all from Gibco, Paisley, UK). Human uterine myometrium smooth muscle cells (PHM1-41), obtained from American Type Culture Collection (ATCC ${ }^{\ominus}$ CRL-3046 ${ }^{\mathrm{TM}}$ ) were maintained in ATCC-formulated DMEM (ATCC No. 30-2002) supplemented with $0.1 \mathrm{mg} / \mathrm{mL}$ G-418 (Carl Roth, Zurich, Switzerland), $2 \mathrm{mM}$ glutamine and 10\% (v/ v) heat-inactivated FBS.

hTERT-C3 cells were seeded at a density of $5 \times 10^{4}$ cells $/ \mathrm{mL}\left(5 \times 10^{3}\right.$ cells per well $)$ and PHM1-41 cells at a density of $8 \times 10^{4}$ cells $/ \mathrm{mL}\left(8 \times 10^{3}\right.$ cells per well $)$ into transparent 96 -well microplates. 1 day after seeding, cells were exposed to BPJ $(2.5-10.0 \mu \mathrm{g} / \mathrm{mL})$, atosiban $(0.27-$ $1.08 \mu \mathrm{g} / \mathrm{mL})$, nifedipine $(3.0-12.0 \mathrm{ng} / \mathrm{mL})$ or the combinations $\mathrm{BPJ}$ plus atosiban or BPJ plus nifedipine for $24 \mathrm{~h}$. After exposure, resazurin (Alamar Blue, Invitrogen, Illkirch Cedex, France) was added to cells (final concentration 1.0 $\mathrm{mg} / \mathrm{mL}$ ), and the plate incubated at $37^{\circ} \mathrm{C}$ for $4 \mathrm{~h}$. The extent of resazurin reduction was measured in a microplate reader
(SpectraMax Paradigm, Molecular Devices, Berkshire, UK) at 570 and $600 \mathrm{~nm}$. For each substance tested, 4 independent experiments were carried out in quadruplicate. Ethyl methanesulfonate (30 mM) [27] and Triton X-100 (1\%) were used as a positive control. In each experiment, wells with no test substance added to the culture medium served as untreated control (100\% viability). Cell viability was determined according to the following equation:

$$
\text { Viability }=\frac{\left(\mathrm{A}_{570}-\mathrm{A}_{600}\right) \text { sample}-\left(\mathrm{A}_{570}-\mathrm{A}_{600}\right) \text { blank }}{\left(\mathrm{A}_{570}-\mathrm{A}_{600}\right) \text { control- }\left(\mathrm{A}_{570}-\mathrm{A}_{600}\right) \text { blank }}
$$

\section{Cell morphology analysis}

Myometrium hTERT-C3 cells and PHM1-41 cells were stained with fluorescent probes for nuclei (doublestranded DNA) and cytoplasm (F-actin), as follows. After treatment with test substances, alone or combined, for $24 \mathrm{~h}$, cells were washed with phosphate buffered saline (PBS; Gibco, Paisley, UK) and fixed with 4\% paraformaldehyde (PFA; from Artechemis, Zoffingen, Switzerland) in PBS for $20 \mathrm{~min}$. Cells were then permeabilised with $0.3 \%$ Triton X-100 (Sigma, St. Louis, USA) in 1\% bovine serum albumin (BSA; Sigma, St. Louis, USA) for $30 \mathrm{~min}$. Then, cells were incubated with a 1:10000 dilution of $4{ }^{\prime}$, 6-diamidino-2-phenylindole (DAPI; Sigma, St. Louis, USA) and 1:400 rhodamine phalloidin (Invitrogen, Illkirch Cedex, France) prepared in $0.1 \%$ Triton X-100 (Sigma, St. Louis, USA) in $1 \%$ BSA, for $4 \mathrm{~h}$, in the dark. Cells were rinsed with PBS and examined with the Leica CTR 6000 microscope (Leica microsystems, Heerbrugg, Switzerland). The entire procedure was performed at room temperature.

\section{Statistical analyses}

Statistical analyses were performed using GraphPad Prism 7 (GraphPad Software, Inc., CA, USA). In all cases, a significance level of $p<0.05$ was considered statistically significant.

Because of the slightly different experimental set-ups used to investigate the combinations of BPJ with atosiban and of BPJ with nifedipine in the myograph model, different tests were used in the two cases. Data from the combination of BPJ and atosiban measurements were analysed with the Kruskal Wallis test followed by Dunn's multiple comparisons test. Data from the combination of BPJ and nifedipine were analysed with the Wilcoxon test to compare control with BPJ and nifedipine with the combination (determinations in the same strips, paired 


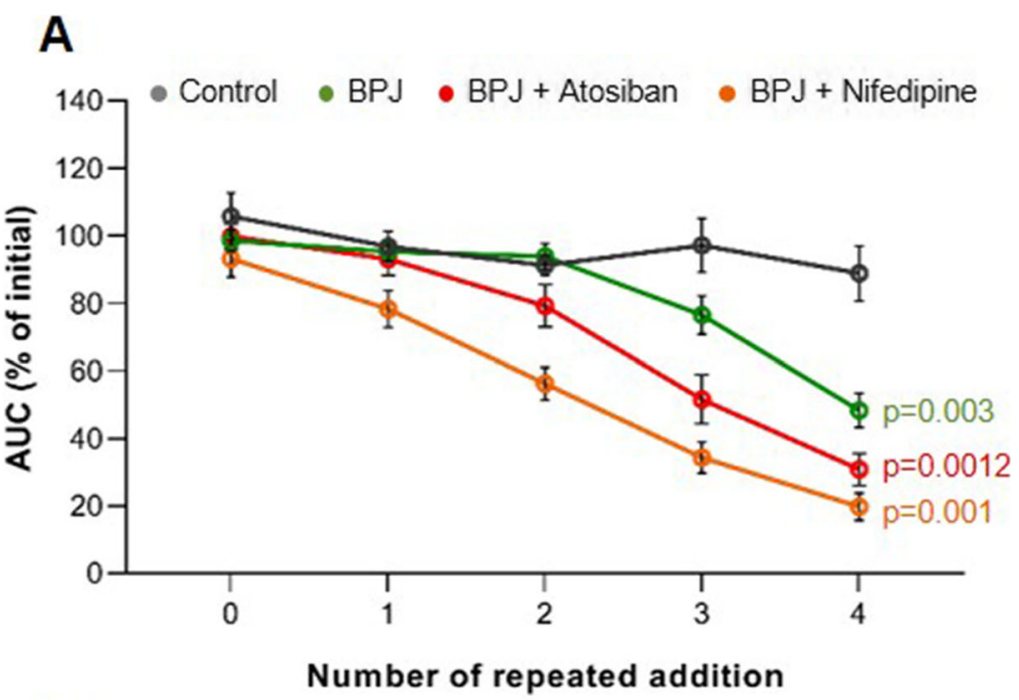

B

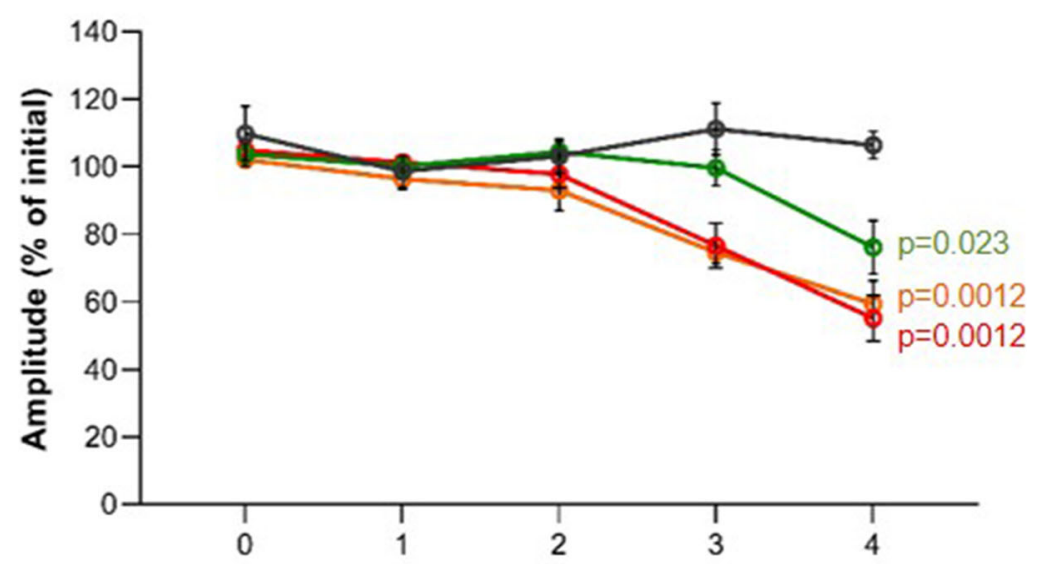

Number of repeated addition

C

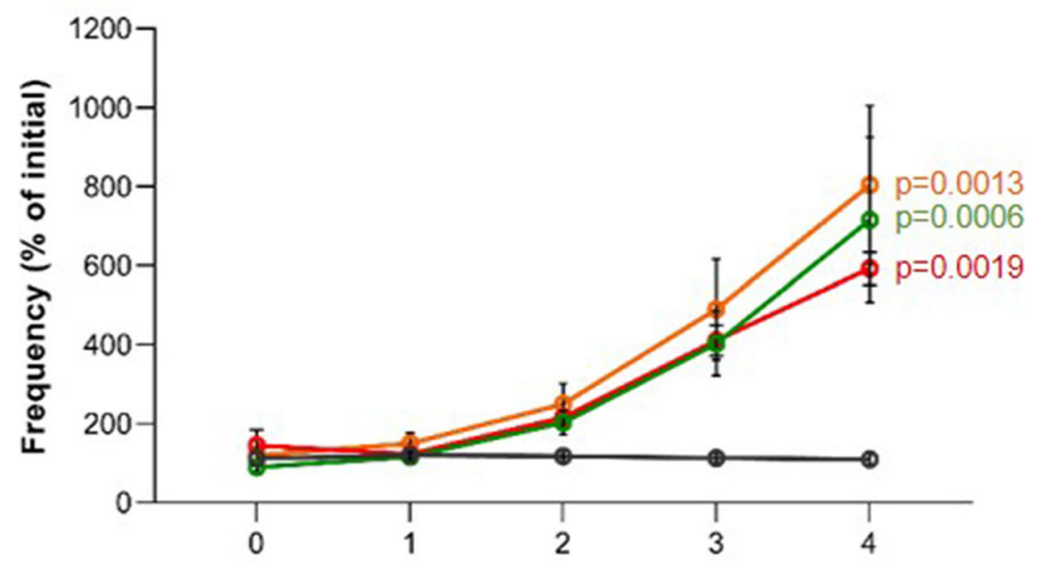

Number of repeated addition

Fig. 3 (See legend on next page.) 
(See figure on previous page.)

Fig. 3 Effect of repeated addition of BPJ plus atosiban $(15 \mu \mathrm{L}$ and $4.3 \mu \mathrm{L}$ of $375 \mu \mathrm{g} / \mathrm{mL}$, respectively) and of BPJ plus nifedipine ( $15 \mu \mathrm{L}$ and $5 \mu \mathrm{L}$ of $3.7 \mu \mathrm{g} / \mathrm{mL}$, respectively) on human myometrial contractility in vitro. All test substances were repeatedly added to the myograph chamber. The line chart shows the AUC (a), the amplitude (b), and the frequency (c). Data were obtained with 5 different biopsies $(n=5)$ and are expressed as percentage of initial. The repeated addition of BPJ was performed for comparison; Krebs solution ( $5 \mu \mathrm{L})$ was used as control. ${ }^{*} p<0.05$

test), and with the Mann-Whitney to compare control with nifedipine and with combination (determinations in different strips, unpaired test). Effects of combination treatments on myometrial contractility are expressed in scatter dot plots as mean values \pm SEM.

For each test substance, dose-dependency data obtained in the myograph model and cell viability data was analysed with the paired, non-parametric Friedman test. Statistical analyses of cell viability data was followed by Dunn's multiple comparisons test. In the case of the single concentrations of positive controls used in cell viability assays, the paired t-test was used to compare their effects with untreated control. Myograph measurements on dose-dependency and cell viability data are given as mean \pm SEM.

\section{Results \\ Effect of BPJ and atosiban on human myometrial contractility}

The exposure of contracting strips to $2.5 \mu \mathrm{g} / \mathrm{mL} \mathrm{BPJ}$ and $0.27 \mu \mathrm{g} / \mathrm{mL}$ atosiban (final concentrations in the bath) led to a decrease of contraction strength (AUC and amplitude; Fig. 2a and b). BPJ alone lowered the AUC to $70.9 \pm 4.7 \%$ of initial, which was significantly different from the control $(p=0.001)$, while $0.27 \mu \mathrm{g} / \mathrm{mL}$ of atosiban lowered AUC to $80.9 \pm 4.1 \%$ of initial. When the combination of BPJ and atosiban was added to the organ bath, the AUC decreased to $48.8 \pm 6.3 \%$, a value significantly different from control and atosiban alone $(p<$ 0.001 and $p=0.03$, respectively; Fig. 2a).

BPJ decreased the amplitude to $91.0 \pm 4.6 \%$ of initial, and atosiban to $93.4 \pm 4.6 \%$ of initial, but the decreases were not statistically significant. The combination of BPJ and atosiban led to a significantly stronger decrease of amplitude ( $80.1 \pm 7.4 \%$ of initial, $p=0.01$; Fig. $2 \mathrm{~b})$ relative to control.

The frequency of myometrial contractions increased with the addition of BPJ to $204.7 \pm 27.8 \%$ of initial, which was significantly higher than with atosiban $(81.0 \pm 10.1 \%$ of initial; $p=0.03$ ). Also, the combination of BPJ and atosiban led to a significant increase of frequency (345.4 $\pm 73.0 \%$ of initial) relative to control and atosiban alone ( $p=0.010$ and $p<0.001$, respectively; Fig. $2 c)$ that per se did not increase frequency.

Stepwise increase of BPJ and atosiban concentrations led to successive decreases of myometrial contractility strength (Fig. 3a and b).
Effect of BPJ and nifedipine on myometrial contractility BPJ, nifedipine, or the combination of the two led to a significant decrease of contractions relative to control (Fig. 4a). BPJ alone lead to a decrease to $78.9 \pm 3.8 \%$ of initial $(p=0.003)$, and nifedipine decreased the AUC to $71.0 \pm 3.4 \%$ of initial $(p<0.001)$. The combination of nifedipine with BPJ had the strongest effect, as the AUC of contractions was lowered to $39.9 \pm 4.6 \%$ of initial, which was significantly different from the effect of nifedipine alone $(p<0.001)$.

The amplitude of myometrial contractions decreased with BPJ $(91.7 \pm 4.7 \%)$, nifedipine $(86.4 \pm 4.4 \%)$, and the combination $(65.4 \pm 5.3 \%)$. Compared to control, the effect of nifedipine $(p<0.001)$ and the combination of BPJ with nifedipine $(p=0.003)$ was significant. The combination of BPJ and nifedipine also significantly decreased the amplitude when compared to nifedipine alone ( $p=0.002$; Fig. $4 \mathrm{~b})$.

As shown in Fig. 4c, BPJ strongly increased the frequency of myometrial contractions to $257.1 \pm 40.6 \%$ of initial $(p<$ 0.001 ). In contrast, nifedipine alone had no effect on frequency when compared to control. However, the combination of BPJ and nifedipine led to an increase of $190.1 \pm$ $22.2 \%$ of initial, which was significantly different from control $(p<0.0001)$ and from nifedipine alone $(p<0.001$; Fig. 4c).

Exposing the strips to successively higher concentrations of the combination of BPJ and nifedipine led to stepwise increases of the inhibitory effects on myometrial contractility (Fig. 3a and b, data on BPJ + Nifedipine).

\section{Effects on myometrial viability}

Under our experimental conditions, myometrium strips were still contracting spontaneously after the washing step at the end of the myograph experiments, revealing that the test substances (single or in combinations) were not toxic to myometrial tissue (data not shown). To assess the cytotoxicity of the test substances using a different read-out, viability experiments were performed with two human myometrial cell lines (hTERT-C3 and PHM1-41). The test substances, alone or in combination, were not cytotoxic at similar or even higher concentrations than those used in the main combinations experiment, and at a markedly longer exposure time (24 h; Fig. 5a). At the end of cell viability experiments, cell morphology was evaluated by fluorescence microscopy. Visual examination revealed that the test substances did not affect the morphology of myometrial cells. In 

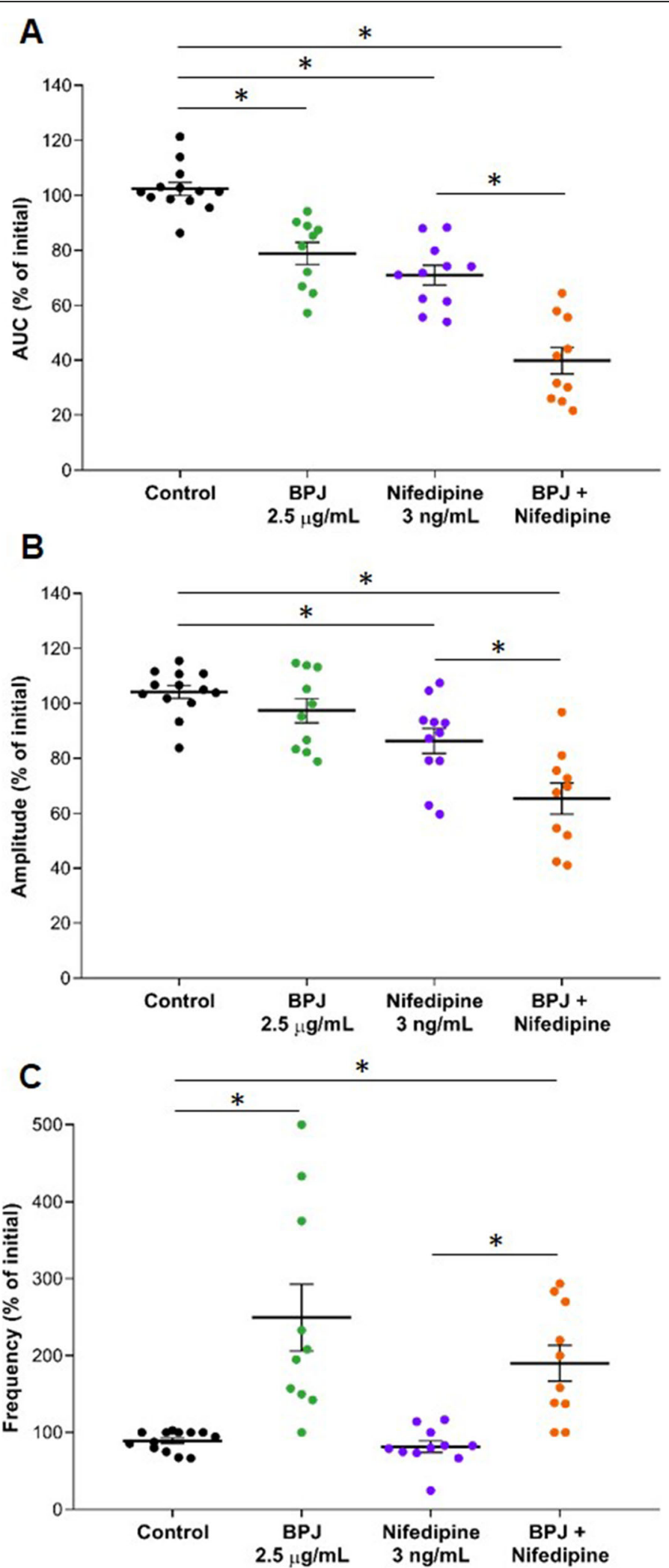

Fig. 4 (See legend on next page.) 
(See figure on previous page.)

Fig. 4 Effect of BPJ, nifedipine, and the combination of BPJ with nifedipine on human myometrial contractility in vitro. BPJ (green; $15 \mu \mathrm{L}$ ), nifedipine (violet; $5 \mu \mathrm{L}$ of $3.7 \mu \mathrm{g} / \mathrm{mL}$ ), or their combination (orange, same concentrations) were added to the myograph chamber. The scatter dot plot shows the AUC (a), the amplitude (b), and the frequency (c) expressed as percentage of initial. Krebs solution was used as negative control (black, $5 \mu \mathrm{L})$. Data were obtained from 11 to 13 different biopsies $(n=11-13)$ and are presented as mean value \pm SEM. * $p<0.05$

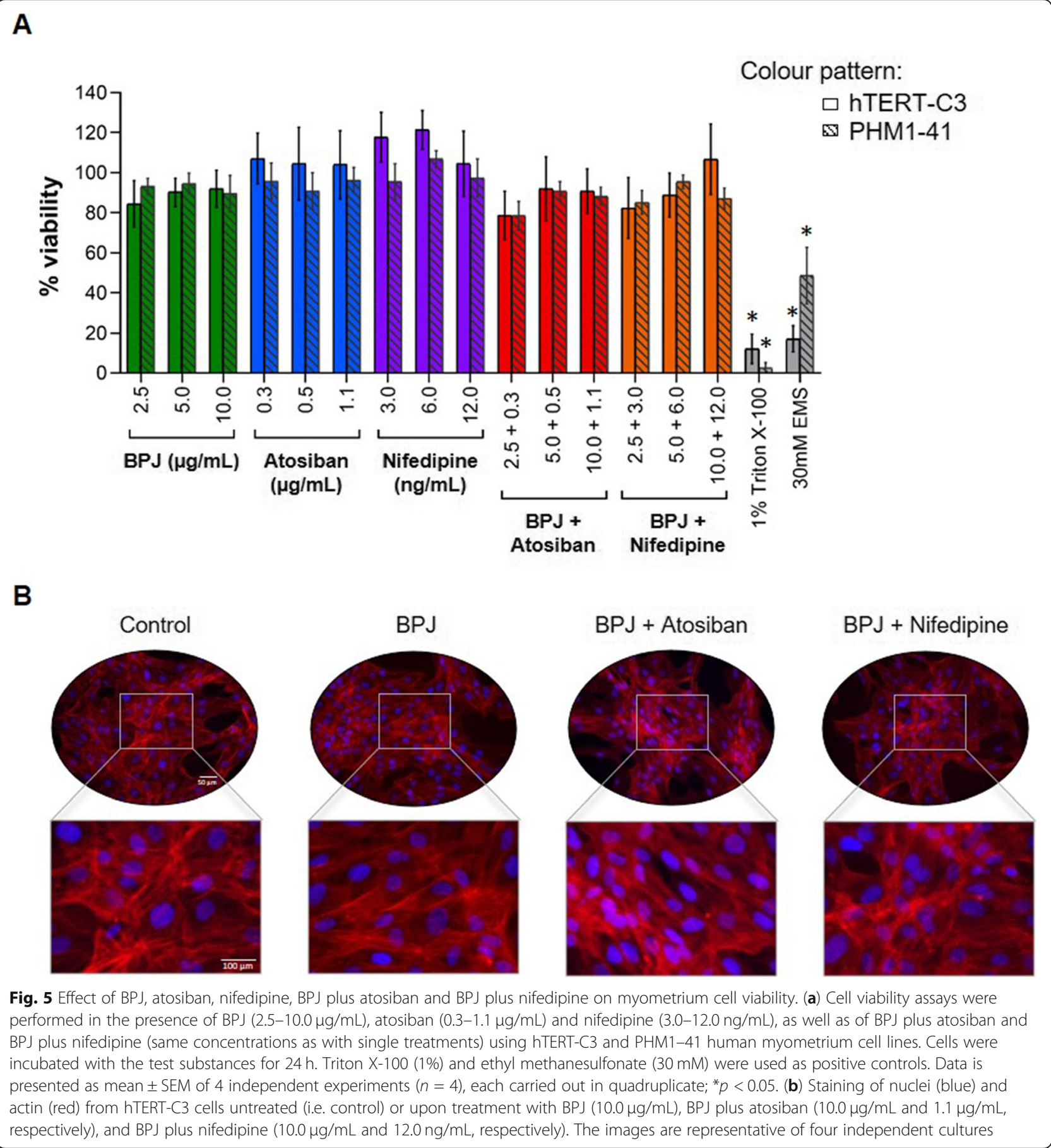


particular, the intact nucleus morphology of hTERT-C3 cells (Fig. 5b) or PHM1-41 cells (data not shown) treated with the highest concentrations of the various test substances reveals that the cells were not undergoing apoptosis.

\section{Discussion}

Press juice from $B$. pinnatum leaves, the active ingredient of chewable tablets that are being used in the management of preterm labour in Switzerland, enhances the inhibitory effect of the oxytocin receptor antagonist atosiban on contraction strength in human myometrium strips. BPJ also enhances the effect of nifedipine, a voltage-dependent calcium channel blocker that is in off-label use as a tocolytic. Both the combination BPJ with atosiban and BPJ with nifedipine show dose-dependent effects on human myometrial contractility. Reduced viability of myometrial tissue or cells does not play a role in the observed results. Taken together, our data corroborate the clinical use of these combination treatments.

The main strength of our study is the use of the physiologically most relevant model to study the process of myometrial contractions in human material, with the possibility to compare the effect of different substances, alone and in combination. In fact, our study depicts a proof of principle for the therapeutic potential of the combination of standard tocolytic medications with BPJ. Alternatives would be animal models, but the process of labour differs between humans and animal species $[28,29]$. Limitations of our model are the availability of myometrium biopsies and the very low throughput that can be achieved with an organ bath model. For these reasons, the number of tested concentrations had to be kept low. Also due to the low throughput, it would be advantageous to further reduce the variability of results (and therefore of needed experiments) in future projects. For this reason, two variant experimental protocols were used in this work. The comparable SEM values obtained indicated that the two protocols were equally suited.

Several signalling pathways are known to increase intracellular calcium concentrations leading to contraction of myometrium cells. Some of these pathways are triggered by binding of oxytocin to the corresponding G-protein coupled receptor, but membrane depolarisation with concomitant opening of voltage-gated calcium channels may also play a role [30]. The two tocolytics used in the present study prevent the increase in intracellular calcium concentration by different mechanisms, namely by blocking oxytocin receptors in the case of atosiban, or by blocking voltage-gated calcium channels in case of nifedipine [11]. Previous work showed that BPJ inhibits oxytocin-induced increase of intracellular calcium concentration in myometrium cells. BPJ did not prevent, but delayed the depolarisation-induced increase of intracellular calcium in cells with voltage-gated channels [31]. In myometrial strips, the combination of atosiban with calcium-channel blockers (nicardipine or nifedipine) led to additive inhibitory effects, indicating that simultaneous targeting of these two pathways has clinical potential [32, 33]. Therefore, it appears conceivable that the delaying effect of BPJ on depolarisation-induced increase of intracellular calcium can enhance the effects of atosiban. Likewise, the inhibition of oxytocin-induced increase of intracellular calcium concentration by BPJ should synergise with the effects of nifedipine. To which extent inhibition by BPJ of each of these two signalling pathways contributes to the observed in vitro results or to the effectiveness of $B$. pinnatum preparations in the treatment of preterm labour is currently not known.

BPJ is known to increase the contraction frequency of myometrium strips $[19,20]$ and this was also observed in the combination with atosiban or nifedipine (Figs. 2, 3 and 4). Our previous work suggests that various components of $B$. pinnatum leaves might contribute to increase contraction frequency of myometrium strips [24]. Both a bufadienolide-enriched fraction and a flavonoid-enriched fraction (but not the corresponding flavonoid aglycon mixture) seemed to contribute to the frequency increase. Whether the signalling pathways activated by BPJ might trigger a partial membrane-depolarisation reserves further investigations. Trying to translate the increase in frequency seen in myometrium strips into the clinical situation, we feel tempted to suggest that B. pinnatum preparations but not other tested tocolytics - could induce a type of conversion of labour-contractions into other, high frequency and painless, and most importantly not-effective, contractions. These are well known in the praxis, and often interpreted as myometrium training uterine contractions that do not lead to labour. In retrospective studies on the tolerability of $B$. pinnatum, no clinically relevant increases of contraction frequency have been observed, neither when used as single treatment nor in combination with tocolytics $[15-17,23]$. Also, no increase was reported in a prospective observational study which even included women with uterine tachysystoles [22]. On the contrary, a significant lowering of contraction frequency was observed after $4 \mathrm{~h}$ of treatment with $B$. pinnatum $50 \%$ tablets in a previous randomised trial on acute tocolysis $(n=13)$ [18].

Although the main combination experiments were performed in vitro and with concentrations leading to moderate effects, we compared the concentrations of atosiban and nifedipine used in vitro with the corresponding plasma concentrations during tocolysis. In the case of atosiban, the mean plasma concentration at steady state is $0.44 \pm 0.07 \mu \mathrm{g} / \mathrm{mL}$ [34], and in the case of nifedipine is $67.4 \pm 28.4 \mathrm{ng} / \mathrm{mL}$ [35]. Therefore, whereas the concentration of atosiban in the myograph experiments is rather close to that measured in the plasma, the 
concentration of nifedipine was markedly lower. Given the lack of pharmacokinetic data with BPJ, it is not possible at this point to compare the concentration in the myograph experiments with known plasma concentrations.

Currently used standard tocolytic treatments are not always able to prolong pregnancy for at least $48 \mathrm{~h}$ [7]. At the same time, combinations of standard tocolytics are not recommended by the Swiss Society for Gynaecology and Obstetrics current Swiss guidelines [36], nor by the guidelines from the National Institute for Health and Care Excellence (NICE) [37] because of concerns about side-effects. Our data show that BPJ enhances the inhibitory effect of atosiban and nifedipine on myometrium contractility. In Germany and Switzerland, B. pinnatum preparations (containing BJP as the active ingredient) have been used for decades in clinics and private practices of anthroposophic medicine $[15,16,38]$. In Switzerland, B. pinnatum preparations are being recommended [21] and used to stop pre-term contractions also in conventional clinical practice, often as an add-on treatment $[22,23]$. In the case of atosiban, a combination at low dosages with $B$. pinnatum would lower the overall medication costs. As for nifedipine, a lowering of the dosage in a combination with $B$. pinnatum would have the advantage of limiting the well-known cardiovascular side effects, such as palpitations, hypotension, flushes, headache, and gastro-intestinal symptoms like gastric upset and constipation [39].

\section{Conclusion}

We provide here evidence for the potential of drug combinations of atosiban and nifedipine with $B$. pinnatum. Such combinations may lower the required dosage of tocolytics, thereby decreasing treatment costs and reducing maternal and foetal side effects. This could help to reduce early tocolysis failure and to increase the percentage of patients that reach a $48 \mathrm{~h}$ delay of delivery. Prospective randomised studies are needed to substantiate such combination treatments.

\section{Abbreviations}

AUC: Area under the curve; BPJ: Bryophyllum pinnatum leave press juice

\section{Acknowledgements}

The authors thank Alexandra Dolder for excellent technical support, and all professionals at the University Hospital Zürich, Department of Obstetrics, who facilitated the collection of myometrium biopsies. We are grateful to Dr. Niels Hagenbuch, Institute of Epidemiology, Biostatistics and Prevention, University of Zurich, for statistical support. We are indebted to all other members of the Bryophyllum Study-Group for stimulating discussions.

\section{Author's contributions}

SS, CH, UM and APSW designed the study. SS performed the experiments, analysed the data and wrote the first version of the manuscript, under the supervision of APSW. CH recruited the patients and organised biopsy collection. MH and MM were involved in the interpretation of data and provided critical revision of the manuscript. All authors were closely involved in revising the article and agreed with the final version.

\section{Funding}

Financial support was provided by Weleda AG and the Johannes Kreyenbühl Foundation. The sponsors had no influence on data collection, management or analysis of the data.

\section{Availability of data and materials}

Data obtained during the current study are available from the corresponding author on reasonable request. The biological materials used (myometrium strips) are not available since they have to be used fresh.

\section{Ethics approval and consent to participate}

This study was approved by the ethics committee of canton Zurich (KEK-ZHNr. 2014-0717, approval date 12.05.2015). Written informed consent was obtained the day before surgery.

\section{Consent for publication}

Not applicable.

\section{Competing interests}

MM is an employee of Weleda AG, the company that produces the preparations of Bryophyllum pinnatum. APSW received research funding from Weleda AG during the last 5 years.

\section{Author details}

${ }^{1}$ Department of Obstetrics, University Hospital Zurich, Schmelzbergstrasse 12/ PF 125, 8091 Zurich, Switzerland. 'Division of Pharmaceutical Biology, University of Basel, Basel, Switzerland. ${ }^{3}$ Weleda AG, Arlesheim, Switzerland.

Received: 25 January 2019 Accepted: 10 October 2019

Published online: 04 November 2019

\section{References}

1. World Health Organization [http://www.who.int/mediacentre/factsheets/ fs363/en/].

2. Blencowe H, Cousens S, Chou D, Oestergaard M, Say L, Moller A-B, Kinney M, Lawn J. Born too soon: the global epidemiology of 15 million preterm births. Reprod Health. 2013;10(1):S2.

3. Lawn JE, Davidge R, Paul VK, von Xylander S, de Graft JJ, Costello A, Kinney MV, Segre J, Molyneux L. Born too soon: care for the preterm baby. Reprod Health. 2013;10(1):S5

4. Romero R, Dey SK, Fisher SJ. Preterm labor: one syndrome, many causes Science. 2014:345(6198):760-5.

5. Arrowsmith S, Kendrick A, Wray S. Drugs acting on the pregnant uterus. Obstet Gynaecol Reprod Med. 2010;20(8):241-7.

6. Schleußner E. The prevention, diagnosis and treatment of premature labor. Dtsch Arztebl Int. 2013:110(13):227.

7. Haas DM, Imperiale TF, Kirkpatrick PR, Klein RW, Zollinger TW, Golichowski AM. Tocolytic therapy: a meta-analysis and decision analysis. Obstet Gynecol. 2009;113(3):585-94.

8. Flenady V, Reinebrant HE, Liley HG, Tambimuttu EG, Papatsonis DN. Oxytocin receptor antagonists for inhibiting preterm labour. Cochrane Database Syst Rev. 2014 Jun;6(6):CD004452.

9. Flenady V, Wojcieszek AM, Papatsonis DN, Stock OM, Murray L, Jardine LA Carbonne B. Calcium channel blockers for inhibiting preterm labour and birth. Cochrane Database Syst Rev. 2014;6:1-34.

10. van Vliet EO, Schuit E, Heida KY, Opmeer BC, Kok M, Gyselaers W, Porath MM, Woiski M, Bax CJ, Bloemenkamp KW. Nifedipine versus atosiban in the treatment of threatened preterm labour (assessment of perinatal outcome after specific Tocolysis in early labour: APOSTEL III-trial). BMC Pregnancy Childbirth. 2014;14(1):93

11. Haram K, Mortensen JHS, Morrison JC. Tocolysis for acute preterm labor: does anything work. J Matern Fetal Neonatal Med. 2015;28(4):371-8.

12. Van Vliet EO, Nijman TA, Schuit E, Heida KY, Opmeer BC, Kok M, Gyselaers W, Porath MM, Woiski M, Bax CJ. Nifedipine versus atosiban for threatened preterm birth (APOSTEL III): a multicentre, randomised controlled trial. Lancet. 2016:387(10033):2117-24.

13. Baschat AA, Cosmi E, Bilardo CM, Wolf H, Berg C, Rigano S, Germer U, Moyano D, Turan S, Hartung J. Predictors of neonatal outcome in earlyonset placental dysfunction. Obstet Gynecol. 2007;109(2, Part 1):253-61. 
14. Kienle GS, Albonico H-U, Baars E, Hamre HJ, Zimmermann P, Kiene H. Anthroposophic medicine: an integrative medical system originating in Europe. Global advances in health and medicine. 2013;2(6):20-31.

15. Fürer $K$, Simões-Wüst AP, von Mandach U, Hamburger M, Potterat $O$ Bryophyllum pinnatum and related species used in anthroposophic medicine: constituents, pharmacological activities, and clinical efficacy. Planta Med. 2016;82(11/12):930-41.

16. Hamburger M, Potterat $O$, Furer $K$, Simoes-Wüst AP, von Mandach U. Bryophyllum pinnatum-reverse engineering of an Anthroposophic herbal medicine. Nat Prod Commun. 2017;12(8):1359-64.

17. Plangger N, Rist L, Zimmermann R, von Mandach U. Intravenous tocolysis with Bryophyllum pinnatum is better tolerated than beta-agonist application Eur J Obstet Gynecol Reprod Biol. 2006;124(2):168-72.

18. Simões-Wüst AP, Lapaire $O$, Hösli I, Wächter R, Fürer K, Schnelle M, Mennetvon Eiff $M$, Seifert B, von Mandach $U$. Two randomised clinical trials on the use of Bryophyllum pinnatum in pre-term labour - results after discontinuation. Complementary Medicine Research. 2018.

19. Gwehenberger B, Rist L, Huch R, von Mandach U. Effect of Bryophyllum pinnatum versus fenoterol on uterine contractility. Eur J Obstet Gynecol Reprod Biol. 2004;113(2):164-71.

20. Wächter R, Brenneisen R, Hamburger M, Mennet M, Schnelle M, Worel A, Simões-Wüst AP, Von Mandach U. Leaf press juice from Bryophyllum pinnatum (Lamarck) Oken induces myometrial relaxation. Phytomedicine. 2011;19(1):74-82.

21. Schenkel L, Simões-Wüst AP, Hoesli I, von Mandach U. Drugs in pregnancy and lactation - medications used in Swiss obstetrics. Z Geburtshilfe Neonatol. 2018;222:1-14.

22. Fürer $K$, Simões-Wüst AP, Winkler A, Amsler N, Schnelle M, von Mandach U. Die Anwendung von Bryophyllum pinnatum-Präparaten in der Geburtshilfe und Gynäkologie-eine multizentrische prospektive Beobachtungsstudie. Complementary Medicine Research. 2015;22(4):231-6.

23. Simões-Wüst AP, Nietlispach A, Mennet $M$, von Mandach U. Bryophyllum pinnatum use in tocolysis in a conventional setting: a retrospective analysis from obstetric clinical practice. BMC Complement Altern Med. 2017; 17(Suppl 1-333):136.

24. Santos S, Haslinger C, Klaic K, Faleschini MT, Mennet M, Potterat O, von Mandach U, Hamburger M, APJPm S-W. A Bufadienolide-Enriched Fraction of Bryophyllum pinnatum Inhibits Human Myometrial Contractility In Vitro. Planta Med. 2019:85:385-93.

25. Condon J, Yin S, Mayhew B, Word RA, Wright W, Shay J, Rainey WE. Telomerase immortalization of human myometrial cells. Biol Reprod. 2002; 67(2):506-14.

26. Devost $\mathrm{D}$, Zingg HH. Novel in vitro system for functional assessment of oxytocin action. Am J Physiol-Endocrinol Metab. 2007;292(1):E1-6.

27. Ray SD, Fariss MW. Role of cellular energy status in tocopheryl hemisuccinate cytoprotection against ethyl methanesulfonate-induced toxicity. Arch Biochem Biophys. 1994;311(1):180-90

28. Smith R. Parturition. N Engl J Med. 2007;356(3):271-83.

29. Arthur P, Taggart M, Mitchell B. Oxytocin and parturition: a role for increased myometrial calcium and calcium sensitization? Front Biosci. 2007;12:619.

30. Arrowsmith S, Wray S. Oxytocin: its mechanism of action and receptor signalling in the myometrium. J Neuroendocrinol. 2014;26(6):356-69.

31. Simões-Wüst AP, Grãos M, Duarte $C$, Brenneisen R, Hamburger M, Mennet M, Ramos M, Schnelle M, Wächter R, Worel A. Juice of Bryophyllum pinnatum (lam.) inhibits oxytocin-induced increase of the intracellular calcium concentration in human myometrial cells. Phytomedicine. 2010; 17(12):980-6.

32. Doret M, Mellier G, Gaucherand P, Saade GR, Benchaib M, Frutoso J, Pasquier JC. The in vitro effect of dual combinations of ritodrine, nicardipine and atosiban on contractility of pregnant rat myometrium. BJOG. 2003; 110(8):731-4.

33. Kuć $P$, Laudański P, Pierzyński P, Laudański T. The effect of combined tocolysis on in vitro uterine contractility in preterm labour. Adv Med Sci. 2011;56(1):88-94.

34. Goodwin TM, Millar L, North L, Abrams LS, Weglein RC, Holland ML. The pharmacokinetics of the oxytocin antagonist atosiban in pregnant women with preterm uterine contractions. Am J Obstet Gynecol. 1995;173(3):913-7.

35. Papatsonis DN, Bos JM, van Geijn HP, Lok CA, Dekker GA. Nifedipine pharmacokinetics and plasma levels in the management of preterm labor. Am J Ther. 2007;14(4):346-50.
36. Hösli I, Sperschneider C, Drack G, Zimmermann R, Surbek D, Irion O Tocolysis for preterm labor: expert opinion. Arch Gynecol Obstet. 2014; 289(4):903-9.

37. National Institute for Health and Care Excellence (NICE): Preterm labour and birth. In. NICE: National Institute for Health and Care Excellence; 2015.

38. Simões-Wüst AP, Jeschke $E$, Mennet $M$, Schnelle $M$, Matthes $H$, von Mandach U. Prescribing pattern of Bryophyllum preparations among a network of anthroposophic physicians. \2012; 19(6):293-301.

39. Al-Omari WR, Al-Shammaa HB, Al-Tikriti EM, Ahmed KW. Atosiban and nifedipine in acute tocolysis: a comparative study. Eur J Obstet Gynecol Reprod Biol. 2006;128(1):129-34.

\section{Publisher's Note}

Springer Nature remains neutral with regard to jurisdictional claims in published maps and institutional affiliations.
Ready to submit your research? Choose BMC and benefit from:

- fast, convenient online submission

- thorough peer review by experienced researchers in your field

- rapid publication on acceptance

- support for research data, including large and complex data types

- gold Open Access which fosters wider collaboration and increased citations

- maximum visibility for your research: over $100 \mathrm{M}$ website views per year

At BMC, research is always in progress.

Learn more biomedcentral.com/submissions 